\title{
Enhancing Financial Deepening as a Factor of Reducing the Inflationary Pressure in Post-Soviet Economies
}

\author{
Edward Sandoyan • Lidia Davoyan
}

Published online: 3 October 2012

(C) CEEUN 2012

\begin{abstract}
The article considers the issues of inflationary monetization in postsoviet countries and how the deepening of financial intermediation could overcome this. It analyses the current situation of financial intermediation in mentioned countries and finds the institutional obstacles for its further development taking into account the consequences of recent global financial crisis. This implies the reconsideration of some basic concepts of financial intermediation development in postsoviet countries and the model of its regulation and supervision as well.
\end{abstract}

Keywords Monetization - Financial intermediation - Global financial crisis . Financial deepening $\cdot$ Regulation and supervision of financial markets

\section{Introduction}

Contemporary world economy undergoes changes due to the global financial crisis which actually was generated by the unprecedented growth of financial markets and consequently financial flows. These resulted into acceleration of risk importing due to globalization processes. Higher the extent of integration more interpenetrated are risks including inflation risk. Under such circumstances local prices become more elastic to external factors primarily in post-soviet countries characterizing by low efficiency of monetary regulation, antimonopoly policy as well as inadequate development of financial intermediation. As a matter of fact an unprecedented expansion of financial markets means a substantial outflow of financial resources from tangible sector towards financial one. Moreover a significant part of these resources directed into financial

\footnotetext{
E. Sandoyan $(\bowtie) \cdot$ L. Davoyan

Russian-Armenian (Slavonic) University, Yerevan, Armenia

e-mail: edwardsandoyan@gmail.com

L. Davoyan

e-mail: lidia_0783@yahoo.com
} 
sectors of developed countries particularly US (only net inflows of portfolio equities amounted more than 172 billion of US dollar in 2010) instead of developing countries. It's not bad as some investigations proved financial institutes acted at the same time as "producers" and "consumers" of different financial products thus creating new (added) value. Therefore they generate extended reproduction themselves so can be considered not only as a factor of promoting economic growth. ${ }^{1}$ However such increased significance and the role of financial sector nowadays demands an implementation of corresponding regulation and supervision approach particularly at the market of derivatives. Concerning Basel-2 and Basel-3 it should be mentioned that they envisages imperfect regulation for preventing newly originated risks.

As recent crisis evidenced economies with different extents of efficiency of national systems of state regulation of financial markets and institutes perceived the influence of global crisis differently. Institutional differences in the national systems of financial market regulation including EU and USA as well as the lack of consolidated supranational system of global regulation at the basis of unitary rules are the serious barriers for further development of global financial system. For the last 10 years both in USA and different European countries a tendency for weakening national regulative requirements is observed aiming to provide more attractiveness of their financial sectors. Naturally, such development of the events led to emergence of new risks on financial market, losses of which considerably surpassed the gains. And finally in the conditions of expansion of banking activity as well as financial conglomerates the argument developed by national supervision bodies to the effect that internal/local regulators and supervisors are more informed consequently can supervise more efficiently proved to be wrong. ${ }^{2}$ In addition, clear mechanisms and responsibility for elimination of financial instability risks on all-European market have not determined yet. Obviously the necessity to formalize such decisions nowadays became more than outstanding because of the liquidity crisis on the global financial market. For instance, a strict restriction for banking activity in the field of open market operations must be settled. Banks should be prohibited to place assets in shares and derivatives, to carry speculative transactions on exchange market, to allow substantial open currency position and etc. When classifying assets for formation reserves for their possible lose a strict approach to mortgage and consumer credits without initial cover funds should be implemented. It is also important to toughen regulatory requirements concerning the liquidity and creditors' risks. ${ }^{3}$ The provision of high extent of coordination in the sphere of financial regulation and prudential supervision, as well as the harmonization of all the countries legislations seems to be the problem of primary importance. In this context the overall convergence in the concepts, technologies and procedures of regulation and supervision over the global system of financial intermediation has to be achieved. Moreover, a new system of global regulation must be established taking into account the following three basic

\footnotetext{
1 Darbinyan and Sandoyan (2010) "Financial intermediation in contemporary economy"//Journal of International Nobel Economic Forum. 2010, № 1 (3). Vol. 1, p. 97.

2 Prati, Alessandro, Schinasi, Garry J. «Financial stability in European Economic and Monetary Union», International Finance Section, 1999, p. 32.

3 Sandoyan (2007). Problems of modernization of the system of banking regulation in Armenia (monograph)//Yerevan, Publication of RAU, 2007 (in Russian), p. 86.
} 
principles: the centralization of institutes and mechanisms of regulation and supervision on supranational level; consolidation and convergence of the regulation and supervision systems over the all institutes of financial intermediation; strict division of the operational activity spheres between different institutes of financial intermediation (for example, exclusion of banks, pension funds and insurance companies from acting at the derivatives' and corporate securities' markets).

\section{The Analysis of Financial Sector Incompatibility with the Global Framework in Post-Soviet Countries}

Concerning post-soviet countries it should be mentioned that besides essential incompatibility of the regulatory framework of these countries with the global system, there is a necessity of radical modernization of financial institutes including formation of non-banking segments of financial market as capital market, insurance market, private/saving pension system, investment institutes and etc.; many of them still are in embryo or are absent. Particularly problematical the absence of the institutes which "produce" and "consume" long-term financial products, instruments of hedging and insurance of exchange, interest rate risks and etc.

Our investigations showed that most post-soviet countries fall in achieving adequate level of financial sector deepening. However without complete openness of financial sectors of mentioned countries in front of the world financial system it will be impossible to achieve required level of financial intermediation development. Nevertheless most developing and post-soviet countries aspire to integrate their financial sectors into the international financial markets, carrying significant steps towards the unification of legislations, provision of the convergence of the regulation and supervision mechanisms at the basis of Basel standards, development of institutional basis for financial intermediation. However, banking systems of these countries still remain inadequately small and cannot become the providers of foreign banks and other financial organizations in crediting the real sectors of their economies especially in terms of large-scale and long-term projects.

Moreover because of institutional imperfection of national economies in terms of antimonopoly and monetary policies, pricing mechanisms doesn't work properly which makes the influence of external shocks more severe. These external shocks imported into local economies through commodity and financial flows as well. In such a case it is primarily important how national economies can adapt to external shocks. For post-soviet countries an overcoming of the dilemma between restorations of economic growth capacity and insuring macroeconomic stability in post-crisis period is much more difficult task. This emphasizes the necessity of finding the ways of increasing non-inflationary monetization of economy.

\section{The Interdependency of Monetization and Standards of Living}

As our investigations proved, higher the living conditions more non-inflationary is the monetization and vice versa. In other words countries with high level of monetization are also notable for high GDP per capita (see Fig. 1). 

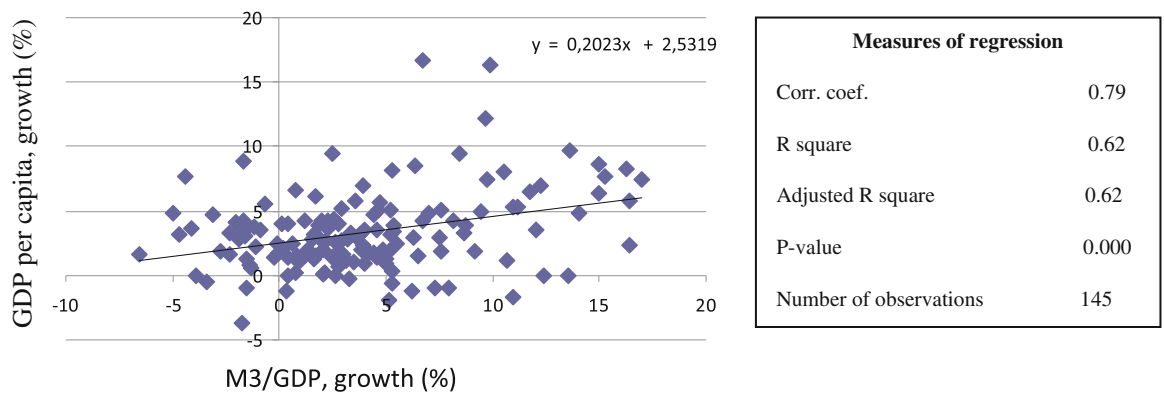

Fig. 1 Regression statistics, 2005-2009. Source World Bank: World Development Indicators, 2011 ( http://devdata.worldbank.org/dataonline/)

Table 1 Percent of population below the poverty line in some post-soviet countries, 2000-2009

\begin{tabular}{llllll}
\hline Belarus & 5,4 & Georgia & 23,6 & Azerbaijan & 15,8 \\
Russian Federation & 11,1 & Ukraine & 7,9 & Kyrgyzstan & 43,1 \\
Kazakhstan & 15,4 & Armenia & 26,5 & Tajikistan & 47,2 \\
\hline
\end{tabular}

Source: Human Development Report 2011. Sustainability and Equity: A Better Future for All. UN, 2011 (http://hdr.undp.org)

Most post-soviet countries have still high level of poverty (see Table 1) and economic growth is considered as the main source of reducing unemployment and eliminating poverty incidence. However almost all these countries face the lack of financial resources in terms of both internal and external finances. The fact is that gross domestic savings in post-soviet countries are in general quite low. For a reasonably representative sample of countries GDS averaged about 24 percent of GDP during the last 5 years. Most post-soviet countries are relatively low savers, they are especially dependent on foreign capital inflows to finance their capital formation. The fact that the small of these inflows came from foreign direct investment, a somewhat more stable source than portfolio investment or private foreign remittances. In some countries like Armenia with large diaspora abroad private foreign remittances which amounted 12-13\% of GDP plays an important role in terms of reducing poverty and inequality. However it seems to be instable source as largely depends on the state of foreign labor markets mainly Russian Federation. Others like RF, Turkmenistan, Azerbaijan, Kazakhstan still largely depends on the natural resources exporting.

The obvious conclusion is that post-soviet economies may find it difficult to recover and then sustain higher levels of economic growth until the inflows of foreign savings and especially the level of domestic savings starts to recover. Since monetization in post-soviet economies remains low it creates difficulties for achieving sustainable economic growth. That's why increasing the level of monetization particularly its long-term components through enhancing financial deepening seems to be a necessary precondition for improving living standards of mentioned countries (Fig. 2). 


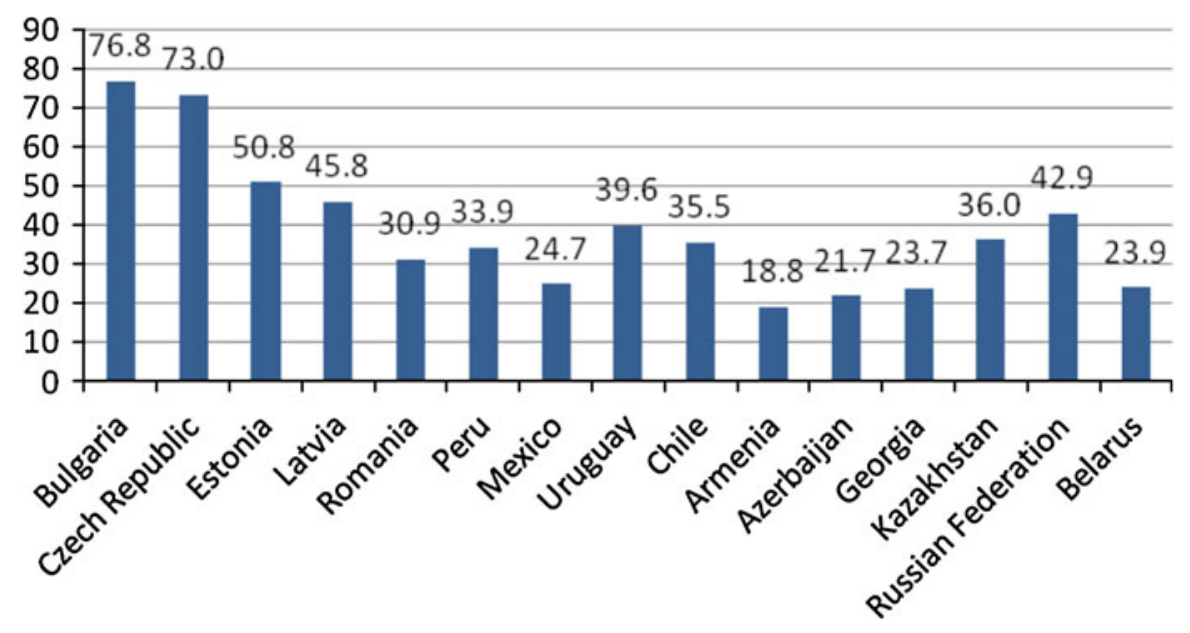

Fig. 2 Level of monetization in selected countries, 2007-2010. Source: World Bank: World Development Indicators, 2011 (http://devdata.worldbank.org/dataonline/)

When comparing the level of monetization of post-soviet economies for the last 5 years with the same indicator by transition economies (see Fig. 1), we consider an average indicator for them slightly more $27 \%$, yielding lots of transition countries, for example Baltic states (an average indicator $50 \%$ ), China (156\%), South Korea (74\%), Brazil (67\%), Chile (35\%) and etc.

At the same time because of the underdevelopment of financial systems in postsoviet countries the increase of monetization leads to inflation growth as in countries with less developed financial intermediation among other financial assets, cash (including foreign currencies) is the commonly used mean of savings and payment. As regards the financial instruments which can absorb excess money there is lack of them on the local markets. That's why at the current phase of economic development the deepening of financial intermediation has a primary importance.

\section{How the Enhancing of Financial Deepening in Transition Countries can Minimizes the Risks of Inflationary Monetization}

Data reflected in the Table 2 indicates that developed financial markets generating "long money" minimize the risk of inflationary monetization. So, countries with large share of financial mediation as a proxy of which we used domestic credit, provided by banking sector, insurance market's assets as well as the share of pension assets in national GDP show low level of inflation and higher living standards than those with emerging financial markets with insufficient development of the financial institutes of postponement of the claim right for money.

Moreover, the latest events taking place in some of transition countries for the last time, particularly the volatility and sharp strengthening of exchange rates of national currencies against US dollar, instability of inflationary expectations and etc. point at the necessity for developing the mechanisms and the tools of financial 
Table 2 Macroeconomic and financial indicators in selected countries, 2010

\begin{tabular}{|c|c|c|c|c|c|}
\hline Country & $\begin{array}{l}\text { GDP per capita, } \\
\text { PPP (current } \\
\text { international \$) }\end{array}$ & $\begin{array}{l}\text { Domestic credit } \\
\text { provided by banking } \\
\text { sector ( } \% \text { of GDP) }\end{array}$ & $\begin{array}{l}\text { Pension } \\
\text { funds' } \\
\text { assets ( } \% \text { of } \\
\text { GDP) }\end{array}$ & $\begin{array}{l}\text { Insurance } \\
\text { market assets } \\
(\% \text { of GDP })\end{array}$ & $\begin{array}{l}\text { Inflation, } \\
\text { consumer } \\
\text { prices } \\
\text { (annual \%) }\end{array}$ \\
\hline Canada & 38,989 & 177.6 & 64.7 & 26 & 1.8 \\
\hline Switzerland & 46,581 & 191.1 & 113.8 & 50 & 0.7 \\
\hline United States & 47,199 & 231.4 & 104.0 & 23 & 1.6 \\
\hline Finland & 36,651 & 100.5 & 82.1 & 22 & 1.2 \\
\hline Chile & 15,732 & 90.3 & 67.0 & 18 & 1.4 \\
\hline $\begin{array}{l}\text { Czech } \\
\text { Republic }\end{array}$ & 25,283 & 64.7 & 6.3 & 11 & 1.4 \\
\hline Estonia & 20,615 & 97.6 & .. & 6 & 3.0 \\
\hline Hungary & 20,029 & 81.7 & 14.6 & 3 & 4.9 \\
\hline Iceland & 34,895 & 166.3 & 123.9 & 93 & 5.4 \\
\hline Mexico & 14,498 & 45.0 & 12.6 & 11 & 4.2 \\
\hline Poland & 19,783 & 63.6 & 15.8 & 6.6 & 2.7 \\
\hline Portugal & 25,610 & 208.9 & 11.4 & 18 & 1.4 \\
\hline $\begin{array}{l}\text { Slovak } \\
\text { Republic }\end{array}$ & 23,423 & .. & 7.4 & 12 & 1.0 \\
\hline Slovenia & 27,063 & 97.4 & 2.5 & 12 & 1.8 \\
\hline Armenia & 5,463 & 25.8 & .. & 1.4 & 8.2 \\
\hline Georgia & 5073 & 33.8 & .. & .. & 7.1 \\
\hline Azerbaijan & 9,943 & 23.5 & .. & 0.5 & 5.7 \\
\hline $\begin{array}{l}\text { Russian } \\
\text { Federation }\end{array}$ & 19,840 & 38.6 & 2.3 & 2.5 & 6.9 \\
\hline Kazakhstan & 12,174 & 45.4 & 11.7 & 2 & 7.1 \\
\hline Turkmenistan & 8,274 &.. &.. &.. &.. \\
\hline Belarus & 13,928 & 45.7 & .. & 1.7 & 7.7 \\
\hline $\begin{array}{l}\text { Kyrgyz } \\
\text { Republic }\end{array}$ & 2,273 & 14.0 & .. & 0.2 & 8.0 \\
\hline Tajikistan & 2,163 & 27.5 & .. & 0.9 & 6.4 \\
\hline Ukraine & 6,721 &.. & .. & 2.9 & 9.4 \\
\hline Uzbekistan & 3,114 & .. &.. & 0.3 & 1.6 \\
\hline
\end{tabular}

Source: OECD, Country statistical profiles 2011 (http://stats.oecd.org/Index.aspx)

market. However, lots of obstacles existing hinder the further development and deepening of the sector. One of them is legislation restrictions limiting the participation of foreign financial institutes at the local markets in some countries.

\section{Conclusion}

We are convinced that in contemporary world it is possible to implement new approaches for regulation the activity of foreign financial institutes at the territory of 
other countries. As the first step we suggest to allow the banks gained high ratings of recognized rating agencies and audit resolutions of high-grade audit companies, head offices of which are situated in G-13 Basel Countries, to establish branches without any preconditions and without separating capital. ${ }^{4}$ Branches should be granted with universal banking license for fulfillment of all kinds of banking activity and should be supervised on the basis of memorandums negotiated between national regulation and supervision bodies (so-called mutual supervision). It envisages that the capital of head bank (holding company) must serve as a basic regulatory capital because the head bank has unlimited responsibility for commitments of the branches. For instance, the branch's activity must be analyzed and estimated based on the indicators of aggregate capital, capital adequacy, single borrower risk, risks on crediting of affiliated persons with bank and etc. of the head bank. The same approach should be implemented to the insurance companies, allowing them to provide insurance services on the local market without the mediation of local insurance companies. Also this approach can be implemented when registering and listing the securities of foreign issuers admitted to be circulated on the local security market if all the problems in the field of mutual recognition of depositary procedures are settled.

In our opinion the implementation of abovementioned institutional changes will create a necessary background for enhancing financial deepening in developing economies.

\section{References}

Darbinyan AR, Sandoyan EM (2010) Financial intermediation in contemporary economy. J Int Nobel Econ Forum. № 1, 1(3):89-99 (in Russian)

Sandoyan EM (2007) Problems of modernization of the system of banking regulation in Armenia (monograph). Yerevan, Publication of RAU (in Russian)

Sandoyan EM (2008) Concerning the problem of choice of the foreign commercial banks branches' activity regulation model in the Republic of Armenia. Collection of scientific works. И741. Information Technologies and Management 2. Yerevan, Encyclopaedia Armenika (in Russian)

\footnotetext{
${ }^{4}$ Sandoyan Ed.M. Concerning the problem of choice of the foreign commercial banks branches' activity regulation model in the Republic of Armenia//Collection of scientific works. И741. Information Technologies and Management 2. Yerevan, Encyclopedia Armenika, 2008, p.17.
} 